\title{
Hidronimia și relevanța sa geografică în Moldova istorică $\breve{~}^{\dagger}$
}

\author{
Ionel Muntele* \\ Facultatea de Geografie și Geologie, Universitatea "Alexandru Ioan Cuza", Bd. Carol I 11, 700506 Iași, România \\ Colectivul de Geografie, Filiala din Iași a Academiei Române, Bd. Carol I 8, 700505 Iași, România
}

\section{Despre articol}

Istoric:

Primit 18 iunie 2018

Acceptat 5 iulie 2018

Publicat 7 octombrie 2018

Cuvinte-cheie:

toponimie

contact lingvistic

semasiologie

\begin{abstract}
Rezumat
Reieșit din preocupările pentru cercetarea evoluției procesului de populare al Moldovei istorice, studiul de față propune o analiză a distribuției spaţiale și a relevanței geografice a hidronimelor din această regiune. În acest scop au fost inventariate un număr de 2040 cursuri de apă, identificate în diverse materiale cartografice. Acestora li s-au atribuit informații suplimentare legate de originea denumirii și semnificație. Demersul utilizează explicaţiile etimologice preluate din literatura de specialiatate consultată și categoriile de relevanță geografică aferente elementelor cadrului natural sau antropic. Dincolo de limitele impuse de lacunele documentare inerente sau de controversele existente în explicarea etimologiei și a sensului unor denumiri, rezultatele produse prin analiza distribuției statistice a categoriilor reținute au constituit suportul unor clasificări tipologice la nivelul bazinelor hidrografice (32 la număr). Concluziile extrase certifică existența unor puternice conexiuni cu răspîndirea unor grupuri etnice (actuale sau din trecut) și cu particularități ale mediului natural ori induse de relații social-economice specifice.
\end{abstract}

\section{Introducere}

Studiul hidronimiei poate fi un auxiliar prețios pentru analiza evoluției procesului de populare a unui teritoriu. Indiciile asupra stratificării unor denumiri acordate de comunitățile care se succed într-un anumit spațiu și contextul care creează anumite semnificații, deseori corelate cu elemente ale cadrului natural și ale mediului social, pot sprijini elaborarea unor ipoteze de lucru sau pot valida concluzii rezultate din analiza informațiilor documentare. În prezentul studiu au fost reținute doar hidronimele care denumesc cursuri de apă (potamonime), un sens restrictiv față de clasica definiție a hidronimului dată de Lebel (1956, p. 1) ${ }^{1}$. În ce privește sintagma terminologică „hidronimie minoră”, invocată deseori în studiu, aceasta nu coincide în totalitate cu microhidronimia, care acoperă și elemente de mici dimensiuni (puțuri, izvoare etc., vezi Urazmetova \& Șamsutdinova, 2017, p. 28).

Dezvoltat la nivel european odată cu lucrările ample ale unor autori precum Топоров \& Трубачев (1962) asupra regiunilor din estul Mării Baltice sau Krahe (1964), studiul hidronimiei a generat controverse asupra originii denumirii celor mai importante cursuri de apă din Europa, considerate a proveni dintr-un străvechi strat pre-indoeuropean, vasconic sau semitic în vestul Europei după Vennemann (2003). Posibilitățile actuale de analiză, bazate pe metode matematice (calcul logaritmic), utilizînd liste Swadesh au condus la concluzii îndrăznețe precum cele furnizate de Peust $(2015$, p. 214), după care 87\% dintre rîurile cu peste $250 \mathrm{~km}$ din Europa au denumiri vechi de cel puțin 2000 de ani iar $25 \%$ pot merge în trecut pînă la cel puțin 20000 ani. Acest autor a inclus în analiză și hidronime din spațiul românesc,

${ }^{\dagger} \mathrm{O}$ versiune anterioară a acestui text a fost prezentată sub formă de comunicare la simpozionul „Toponimia între istorie, geografie și lingvistică”, Iași, 10 mai 2018.

*Adresă de corespondență: imuntele@yahoo.fr.

${ }^{1}$ Autorul citat considera că hidronimele trebuie să includă nu numai denumirile date cursurilor de apă, lacurilor sau mlaștinilor dar și elementelor constitutive ale acestora precum confluențele, cascadele, vadurile, gurile de vărsare, atunci cînd acestea prezintă denumiri distincte. 
Ionel Muntele

pentru unele folosind informații invocate și de autori români. Este cazul Siretului, pentru care se invocă drept primă atestare o sursă bizantină din secolul X, sub forma Sarat pe care Brezianu (2002, p. 146) o explica prin românescul „sărat”.

Hidronimia din spaţiul românesc a beneficiat de o atenție deosebită, atît în studii specifice cît și în lucrări mai complexe. Studierea hidronimelor a rămas, în general, orientată spre descifrarea semnificaţiei hidronimelor majore, în mare parte moștenite din substrat. Dispersate geografic, acestea constituie un subiect interesant pentru studiile comparative. Din perspectivă geografică însă, mult mai interesantă poate fi hidronimia minoră, rezultată adesea dintr-o stratificare mai recentă, relativ ușor de explicat prin corespondența cu limbile actuale.

Pornind de la aceste considerente, studiul a optat pentru spațiul Moldovei istorice ca arie de referință, în limitele anterioare dezmembrării ei succesive $(1774,1812)^{2}$. Dimensiunea teritoriului (circa 94000 $\mathrm{km}^{2}$ ) poate implica prezența unor diferențieri majore din perspectiva distribuției formelor unor hidronime, dar evoluția istorică unitară, cel puțin înainte de 1774, permite ipoteza existenței unor denumiri cu o frecvență ridicată, conforme cel mai adesea specificului cadrului natural. Opțiunea pentru un spațiu de asemenea dimensiuni a fost facilitată și de posibilitățile de procesare informatizată a elementelor de analiză. Dacă în literatura de specialitate sînt mai multe studii asupra unor bazine hidrografice din regiune (Ciubotaru, 2001; Cojocaru, 2005; Butnaru, 2011; Eremia, 2012 și 2017 etc.) sau asupra unor categorii de hidronime (Moldovanu, 1987 și 2007-2008; Raevschi, 2006; Eremia, 2014 etc.), o abordare la scara întregii regiuni, fie și dintr-o perspectivă mai generală cum este cea geografică, lipsește. La o scară chiar mai mare, eforturile în acest sens sînt semnificative, demn de menţionat fiind studiul lui Felecan \& Felecan (2015) asupra straturilor etimologice reflectate în hidronomia românească.

Obiectivul principal al studiului este, în acest context, acela de a evidenția distribuția spațială a unor categorii de hidronime în corelație cu originea și semnificativitatea acestora din perspectiva cadrului natural sau uman-geografic (Ungureanu \& Boamfă, 2006, p. 29). Sînt vizate în primul rînd: morfologia văilor, caracteristicile fizico-chimice ale apei, specificul ecosistemelor, modalitățile de valorificare economică a resurselor locale sau organizarea teritoriului. În acest scop au fost utilizate explicaţiile etimologice extrase din literatura de specialitate parcursă, pentru cazurile controversate (numeroase) fiind acceptate variantele care întrunesc un consens larg.

\section{Materiale și metode}

Pentru a urmări relevanța geografică a hidronimelor din spațiul Moldovei istorice a fost creată mai întîi o bază de date cuprinzătoare incluzînd 2040 cursuri de apă. Identificarea acestora a fost mijlocită de hărțile Direcției Topografice Militare, scara 1:50 000 (HARTA TOP.), ale Fondului Cartografic și Geodezic de Stat din Republica Moldova, scara 1:50 000 (FNDG) și de cele topografice militare sovietice (HARTA URSs), disponibile la scara 1:100 000, pentru teritoriile aparținînd în prezent Ucrainei. Informațiile prelevate au fost confruntate cu cele extrase din surse cartografice mai vechi, inclusiv pentru a stabili corectitudinea unor denumiri sau pentru că sînt omise în sursele actuale: ATLAS MOLD., colecția de hărți ale Bucovinei reeditate în 2013 la Suceava sub coordonarea lui I. Iosep (HARTA BUC.), etc. În acelaşi scop au fost consultate: MDG, GONȚA, MDTM, dicționarele geografice ale Basarabiei (ARBORE) și Bucovinei (GRIGOROVITZA) sau dicționarul hidronimelor din Ucraina (HIDR. UCR.).

Numărul indicat cuprinde toate cursurile de apă cu o lungime mai mare de $5 \mathrm{~km}$ în zona montană, 7 km în zona colinară și $10 \mathrm{~km}$ în zona de cîmpie. Motivația acestei discriminări ține de densitatea rețelei hidrografice, superioară în zona montană. Informația a fost organizată pe bazine hidrografice, mergînd pînă la afluenți de rangul IV sau V, eșantionul fiind cît se poate de reprezentativ. Deși pe materialele cartografice figurează frecvent și cursuri de apă mai scurte, mai ales în aria carpatică, acestea nu au fost luate

\footnotetext{
${ }^{2}$ Inclusiv Bugeacul și bazinele superioare ale afluenților unor rîuri carpatice, din rațiuni de continuitate spațială a unor bazine hidrografice.
} 
în calcul, fiind în schimb introduse în baza de date numeroase văi cu scurgere sezonieră sau intermitentă din zonele mai joase, întrucît unele au dimensiuni apreciabile.

Baza de date primară a inclus, în afara rețelei hidrografice, lungimea exprimată în kilometri. Suportul cartografic necesar reprezentării rezultatelor a fost extras din juxtapunerea hărților topografice în Adobe Illustrator. Organizarea bazei de date are ca referință principală Dunărea, pentru afluenții de ordinul I ai acesteia (Siret, Prut, etc.), respectiv Nistrul și tributarii direcți ai Mării Negre (prin intermediul lagunelor şi limanelor fluviatile). Acestei baze de date primare i-au fost adăugate două serii de informații:

a. asupra originii hidronimelor, separînd mai multe categorii, fiecare hidronim primind un indicativ corespunzător;

b. asupra semnificației, conform explicației etimologice preluate din sursele bibliografice, atribuind fiecărui hidronim un alt indicativ corespunzător.

Prelucrarea informației a presupus mai întîi calculul ponderilor fiecărei categorii de hidronime, pe bazine hidrografice (delimitate astfel încît să rezulte arii cu o întindere apropiată) și pe regiuni fizico-geografice majore (montan-subcarpatic, podiș, cîmpie). Ponderile au fost cartografiate pentru fiecare categorie de hidronime, desprinzînd astfel concluzii preliminare asupra distribuţiei, extensiei spațiale ori grupării acestora în areale distincte.

Informaţiile astfel prelucrate au constituit suportul unor analize suplimentare, pe bazine hidrografice, aplicînd una din metodele curente de clasificare tipologică a ambelor serii de informații: referitoare la origine, respectiv, referitoare la semnificația geografică. Opțiunea pentru clasificările ierarhic ascendente (AHC, „agglomerative hierarchical clustering”), efectuate în programul XLSTAT este argumentată de utilizarea ca factor discriminant a disimilarității exprimate prin distanța euclidiană, adică a diferențelor dintre unitățile statistice reținute (bazinele hidrografice în cazul nostru). Astfel este asigurată gruparea lor în funcție de asemănările profilului distribuției categoriilor analizate, pe baza criteriului minimei varianțe (Hastie et al., 2009, p. 520). Cartografierea rezultatelor a permis astfel obținerea unei imagini sintetice asupra subiectului analizat.

\section{Rezultate și discuții}

\subsection{Distribuția și tipologia hidronimelor după origine}

Pentru prelucrarea primară a informației referitoare la originea hidronimelor au fost reținute 7 categorii: a) hidronime cu origine necunoscută sau incertă (EN); b) hidronime românești derivate din cuvinte de origine latină $(\mathrm{R}) ; \mathrm{c}$ ) hidronime românești derivate din cuvinte de altă origine (exclusiv cele de origine slavă, RD); d) hidronime românești derivate din cuvinte de origine slavă (RSL); e) hidronime de origine slavă (SL); f) hidronime de origine turanică (turcică, TUR); g) hidronime de origine maghiară (MG).

Distribuția spațială a acestor categorii scoate în evidență predominanța hidronimelor românești dar şi ponderea apreciabilă a hidronimelor de origine slavă, turanică sau maghiară. Localizarea acestora corespunde unor arii de interacțiune îndelungată între populația românească și comunităţi slave, turanice sau maghiare: hidronimele de origine slavă $(9,8 \%$ din total) sînt preponderente în nord-vestul regiunii (bazinul Prutului superior, în amonte de Cernăuți), incidența lor descrescînd spre sud-est, în Cîmpia Bugeacului fiind practic absente ${ }^{3}$; hidronimele turanice ( $8 \%$ din total) au o distribuție inversă, predominînd în sud-est și avînd o prezență izolată în rest, cu o tendință de grupare în regiunile mai joase (Cîmpia Prutului mijlociu, de exemplu $)^{4}$; hidronimele de origine maghiară (3,1\% din total) sînt prezente în primul

\footnotetext{
${ }^{3}$ Dacă majoritatea hidronimelor considerate a fi de origine slavă sînt indubitabile, există și unele care suscită discuții. De exemplu cuplul vrîncean Năruja - Nereju, derivat uneori din maghiarul nyír 'mesteacăn'. Топоров \& Трубачев (1962, p. 198) menționează un rîu Naružas în Letonia, un altul numit Narussa în Prusia Orientală şi un afluent al Desnei, Nerussa, numit și Neruza. Originea slavă pare mai sigură chiar și în ipoteza vehiculării unei rădăcini de origine baltică, posibilă în contextul migrației slavilor.

${ }^{4}$ Capacitatea populațiilor turanice de a fixa toponime a fost puternică chiar și în cazurile în care stăpînirea lor a fost vremelnică. De exemplu, în ținutul Hotinului, transformat în raia (1712-1812), un afluent al pîrîului Larga care se varsă în Prut la Lipcani se numește Calangiu, derivat din tc. kalayci, termen desemnîndu-i pe țiganii spoitori.
} 
rînd în bazinele Trotușului și Bistriței, cu o dispersie care acoperă aproape toată zona carpatică, depășind spre est valea Siretului.

Semnificativă este și distribuția hidronimelor românești, derivate din cuvinte moștenite din latină (30,7\% din total) a căror frecvență maximă se întîlnește în partea central-sudică a regiunii (din bazinul Siretului inferior pînă în bazinul Botnei). În nord-vest, de-a lungul fluviului Nistru și în extremitatea sudestică a Bugeacului, frecvența lor este mult mai redusă fără a fi nesemnificativă 5 . Rezistența acestora în zone cu o prezență românească modestă în prezent, este dovada unei îndelungate conviețuiri, contrar opiniilor unor cercetători ucraineni care susțin că hidronimele românești din bazinul Nistrului ar fi tardive (abia din secolul al XVIII-lea), minimalizîndu-le importanța. De exemplu, cele peste 150 hidronime românești inventariate și recunoscute ca atare în partea ucraineană a bazinului Nistrului, sînt considerate „nesemnificative” (Вербич, 2015). Opinii diferite, argumentate documentar, sînt susținute de alți cercetători care, cel puțin pentru Bucovina, atestă o modificare masivă a toponimiei în perioada ocupației austro-ungare, inclusiv prin traducerea sau adaptarea unor denumiri românești în limba ucraineană (Prisacaru, 2013).

Expansiunea populației românești la est de Carpați pare astfel să fi avut și o puternică direcție dinspre sud spre nord și nu numai dinspre aria carpatică spre Nistru, cum este acceptat îndeobște. Frapează în mod deosebit frecvența peste medie a hidronimelor românești din Bugeacul central-vestic (bazinele Cogîlnicului și Ialpuhului, unde chiar și afluenții mari ai acestor rîuri cu denumiri vechi de origine turcică, poartă nume românești, timpuriu atestate: Galbena, Schinoasa, Saca, respectiv, Lunga cu afluentul său Lunguța, Salcia Mare etc.).

O pondere foarte mare o dețin hidronimele românești derivate din cuvinte împrumutate din alte limbi sau moștenite din substrat, distribuite relativ uniform (43,2\% în total, cele mai multe împrumuturi slave, anume 23,6\%). Se observă o strînsă corelație între frecvența hidronimelor de origine slavă și a celor derivate din cuvinte românești împrumutate din limbi slave, cu o incidență superioară mediei în jumătatea nord-estică a regiunii (Bucovina, nordul Basarabiei). Putem vorbi despre manifestarea unei influențe slave permanente în aceste zone, spre deosebire de restul regiunii unde aceasta este mai veche. Hidronimele românești derivate din împrumuturi din alte limbi decît cele slave sînt mai frecvente în bazinele mijlocii ale Siretului, Prutului și Nistrului, separînd practic o arie cu influență slavă puternică din nord-vest de aceea cu influențe turanice din sud-est.

O situație aparte o prezintă cele 106 hidronime cu origine controversată sau necunoscută $(5,2 \%$ din total), inegal distribuite, cu o frecvență mare în lungul Nistrului (pînă la 20\% în sectorul din amonte de confluența cu pîrîul Naslavcea). Cele mai multe sînt unice dar unele denumesc mai multe cursuri de apă, de exemplu Molnița (afluent al Siretului sau al Prutului) ${ }^{6}$, Burla (afluent al Sitnei sau afluent al pîrîului Iaslovăț, tributar al Solcăi în bazinul Sucevei), Stemnic/Stebnic (afluent al Bîrladului, respectiv al Siretului, pe cursul superior), Buhalnița (afluent al Bistriței, respectiv al Bahluiului) etc. Există și hidronime care derivă dintr-o temă comună, precum seria Drislea/Dresleuca/Drislavăț ${ }^{7}$. Unele dintre aceste hidronime poartă denumiri interesante din perspectivă etimologică, de exemplu, Dona, afluent pe stînga al Prutului, la Drepcăuți $(14 \mathrm{~km} \text {, raionul Briceni, Republica Moldova })^{8}$. Foarte multe dintre acestea au denumiri „ciudate” în context local, posibil a fi elucidate prin expertiză lingvistică. Putem menţiona astfel în lungul

\footnotetext{
${ }^{5} \mathrm{Cu}$ prezențe notabile totuși precum rîul Sărata în estul Bugeacului sau numeroase pîraie tributare Nistrului în ținutul Hotinului (Chetrosul, Puțita, Țarălungă, Surda, Secureanca ș.a.), ale căror denumiri s-au păstrat în pofida modificării structurii etnice. În unele cazuri denumirea locală, românească s-a păstrat doar în cursul superior, de exemplu Alcalia, în estul Bugeacului, este numită Răpciuga spre izvoare, inclusiv în documente mai vechi.

${ }^{6}$ Acesta este explicat neconvingător de Raevschi (2006, p. 102) prin lituanianul molis ' $m$ îl' și este considerat a proveni din substrat. $\mathrm{Cu}$ aceeași temă, moln-, s-a format și denumirea unui afluent al Ciulucului de mijloc, Molnicul, în bazinul inferior al Răutului. În bazinul Niprului, Топоров \& Трубачев (1962, p. 196) menționează numeroase hidronime cu aceeași temă: Moline, Molina, Molupis, Molingiris.

${ }^{7}$ Raevschi (2006, p. 105) le compară cu letonul Driksne sau cu prusianul Driksna; un afluent pe stînga Desnei, documentat în HIDR. UCR. (p. 183) se numește Drișleva. La începuturile Evului Mediu, zona era populată de triburi baltice.

${ }^{8} \mathrm{Ne}$ referim la posibilitatea derivării din rădăcina iraniană don, desemnînd un curs de apă în limba osetinilor din Caucaz, urmași ai alanilor.
} 
Nistrului, în fostele ținuturi Hotin și Soroca: Midotiul ( 9 km, tributar al Miuscăi la Rașcov); Surșa, cu afluentul său Șost $(21 \mathrm{~km}$, respectiv, $10 \mathrm{~km}$, afluent la Nahoreni, raionul Chelmenți); Șeinu (12 km, afluent la Molodova, raionul Secureni); Burbonea (10 km, afluent la Vetreanca, raionul Secureni), Ojovul (7 km, afluent la localitatea omonimă, de la N de Secureni),Voromid ( $9 \mathrm{~km}$, afluent la Iorjnița, raionul Soroca); Voșcasac și afluentul său Văcăsar (15, respectiv 9 km, afluent la Sănătăuca) etc. ${ }^{9}$ Astfel de denumiri nu lipsesc în restul Moldovei dar sînt mai disperse. Putem menționa: Argiul, un mic afluent de dreapta pe cursul superior al Siretului, Carecna (27 km, afluent pe dreapta al Siretului la Pufești, județul Vrancea), Cuțigna (19 km, numit și Rediu, afluent pe dreapta al Vasluiului), în bazinul Siretului; Tata $(14 \mathrm{~km}$, afluent al Lopatnicului la Briceni, Republica Moldova), Aluza $(15 \mathrm{~km}$, afluent pe dreapta al Jijiei la Iacobeni, județul Iași) în bazinul Prutului; Țaul ( $9 \mathrm{~km}$, afluent pe dreapta al Cuboltei, la satul omonim), Segala (31 km, afluent pe stînga al Răutului la Sărătenii Vechi, raionul Telenești), Moț̦a (27 km, afluent pe dreapta al Răutului la Brănești), Alvnagar (11 km, afluent al Molovatețului, la Ghermănești, raionul Telenești), în bazinul Răutului; Arpintea ( $8 \mathrm{~km}$, afluent al pîrîului Știubei în bazinul Nistrului inferior $\left.{ }^{10}\right)$, etc.

Dacă grupăm hidronimele românești derivate din cuvinte de origine latină și cele derivate din cuvinte împrumutate din alte limbi sau moștenite din substrat, obținem o pondere de 73.9\%, suficient de consistentă pentru a considera că fondul hidronimic dominant este românesc, în acord și cu alți specialiști (Eremia, 2012, p. 73). Chiar și în nord-vestul populat predominant în prezent de etnici ucraineni se ating valori de 43.8-55\%, iar în sud-estul extrem, care păstrează încă amprenta puternică a nomazilor turanici, se ajunge la 29,2-37,7\%. În restul regiunii, valorile sînt apropiate de medie, cu o maximă specifică văii Siretului mijlociu (între confluența Sucevei și cea a Bistriței, incluzînd bazinul Șomuzului Mare, 91,2\%), poate nu întîmplător dacă ne gîndim că în vecinătate se află vechea capitală medievală Baia.

Clasificarea tipologică efectuată conform metodologiei prezentate propune existența a șase arii distincte din perspectiva combinării hidronimelor după origine (Fig. 1). Pentru a ușura înțelegerea modului în care s-au diferenţiat tipurile, materialul grafic include dendograma (clusterul) și profilul grafic al tipurilor, exprimat în unități procentuale. Trebuie specificat că tipologia a avut în vedere răspîndirea categoriilor reținute din fiecare bazin hidrografic în raport cu celelalte și nu predominanța acestora în cadrul aceluiași bazin.

Un prim tip acoperă partea central-sudică a Moldovei istorice, cu extindere în lungul văii Prutului spre Dunărea de Jos. Este aria cu cea mai mare pondere a hidronimelor românești (inclusiv a celor derivate din împrumuturi). Este încadrat de tipul 2, o arie mai vastă care acoperă partea mediană a regiunii (interfluviul Siret-Prut, cu extensii spre bazinele Moldovei, Sucevei şi Prutului mijlociu), în care ponderea hidronimelor de origine slavă este semnificativ mai importantă. Lateral, se disting alte două arii, aferente tipurilor 3 și 4, în a căror structură, similară în mare parte tipurilor 1 și 2 , se impune prezența într-o pondere însemnată a hidronimelor de origine maghiară (tipul 3, cantonat în aria carpatică și subcarpatică), respectiv turanică (tipul 4, extins în partea central-nordică a Basarabiei).

Tipul 5 grupează o fișie sub formă de arc de cerc, din bazinul Ceremuşului pînă pe Nistrul mijlociu amonte de confluența cu Răutul, arie în care ponderea hidronimelor slave este foarte importantă, inclusiv sub formă derivată sau adaptată în limba română. O altă particularitate, deja amintită, o constituie prezența frecventă a unor hidronime cu origine neclară. Dacă în nord-vest, prezența predominantă a populației ucrainene justifică această situaţie, în lungul văii mijlocii a Nistrului, pe teritoriul actual al Republicii Moldova, această structură poate fi pusă pe seama unei prezențe slave masive în trecut. Între

\footnotetext{
${ }^{9}$ Unele dintre acestea par a fi parvenit deformate, nefiind găsite paralele în hidronimia din spațiul mai vast est-european. Forma unora pare a fi slavă, de exemplu Ojovul, atestat timpuriu dar incert (GONȚA, p. 179) ca Ojogov, dar poate fi apropiată și de hidronime ca Ajovka, Ajevka, din bazinul superior al Niprului, explicate de Топоров \& Трубачев (1962, p. 175) prin lituanianul ožis sau letonul ažis 'țap'. Șostul ar putea fi comparat cu un afluent al Desnei, Șostka pentru care este propusă derivarea de la mecm 'lăcrămioară, din dialectele ucrainene de nord-est.

${ }^{10}$ Acest hidronim ar putea fi pus în legătură cu maghiarul árpa sau cu turcescul arpa, ambele avînd aceeaşi semnificație: 'orz'. Dacă ținem cont că acest mic curs de apă este în vecinătatea localității Ciobîrciu (raionul Ștefan Vodă), unde Bandini menționa o comunitate catolică de 200 persoane la 1646, prima variantă pare plauzibilă.
} 
Ionel Muntele

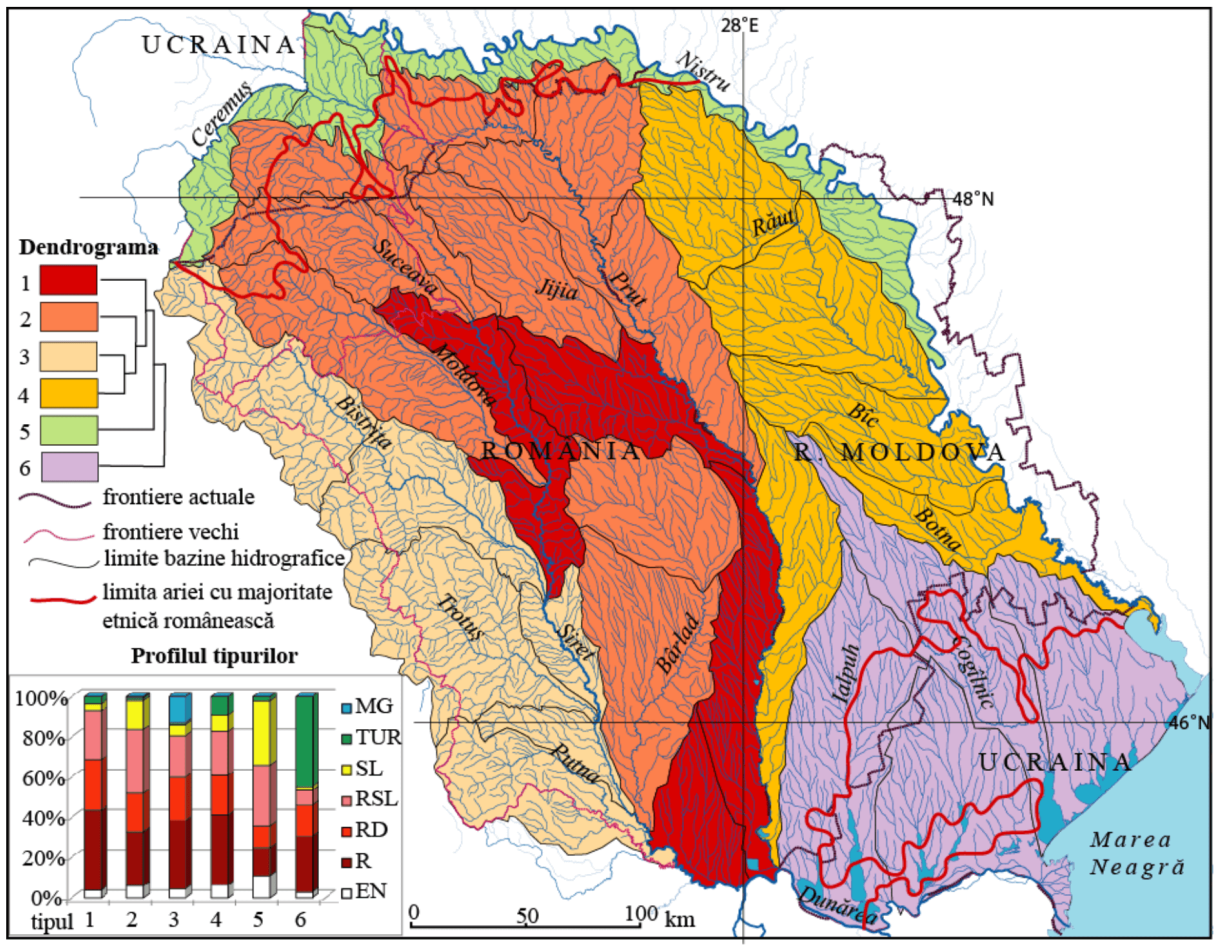

Figura 1: Tipologia hidronimelor din Moldova după origine

Răut și Nistru ar fi fost așezat, după opiniile unor cercetători, tribul slav al tiverților, pomenit în cronicile medievale rusești (Spinei, 1999, p. 113). Masiva influență slavă în hidronimie pare a fi provenit din mai multe direcții: cea mai importantă, dinspre nord-vest, coborînd pe văile Prutului, Siretului și afluenților acestora; dinspre nord-est, difuzată în lungul văii Nistrului mijlociu și a afluenţilor săi basarabeni; dinspre sud spre nord-est, în special în lungul Bîrladului, în bazinul căruia este posibil să interfereze cu celelate două, generînd astfel o frecvență a hidronimelor de origine slavă superioară mediei ${ }^{11}$.

Ultimul tip, 6, este foarte clar personalizat prin combinația dintre hidronimele de origine turcică și cele de origine românească, aproape la paritate. Slaba prezență a hidronimelor de origine slavă (cele mai multe adaptate în limba română) poate fi pusă pe seama utilizării Bugeacului ca bază de expansiune a unor populații nomade sau ca arie de tranzit. Surprinzătoare este însă prezența masivă și durabilă a hidronimelor românești (inclusiv în cazul unor gîrle care leagă Dunărea de lacurile din sudul Basarabiei) ${ }^{12}$. La prima vedere s-ar putea afirma că populația românească a creat probabil primul sistem durabil de aşezări, în special în zona colinară din lungul Prutului (colinele Tigheciului, sediul uneia dintre „republicile” menţionate de Cantemir) sau din lungul Nistrului (satele „hănești” dintre rîul Botna și limanul Nistrului) ori pe terasele lacurilor din lungul Dunării. În acest mod, populațiile colonizate de Imperiul Țarist după 1812 au preluat hidronimia locală românească sau turanică, contribuția lor la diversificarea bazei toponimice fiind redusă ori impusă artificial, prin măsuri oficiale.

Dincolo de aceste diferențe regionale, dacă analizăm distribuția originii hidronimelor după mari unități fizico-geografice (munți, podișuri și cîmpii), constatăm o extindere predilectă a anumitor categorii. Hidronimele de origine turcică sînt prezente (cu mici excepții) preponderent în zonele de cîmpie sau în ariile colinare joase, fiind strîns legate de accesibilitate, element esențial pentru populațiile nomade, din

\footnotetext{
${ }^{11}$ Există multe corespondențe între numele unor afluenți/subafluenți ai Bîrladului și unele bazine hidrografice din Ucraina, atît din vest (Stavnik, Stebnik în bazinul Nistrului superior), cît și din nord-est (Jiroveț/Jeraveț, Sacovița în bazinul Niprului mijlociu), sau din est (Luhan, afluent al Donețului). În același timp, unii afluenți par să trădeze o origine slavă meridională (Gîrbovăț, Bîrzota etc.).

${ }^{12}$ De exemplu, Lata, care leagă Dunărea de Lacul Cahul, Repedea Mare și Repedea Mică, asugurînd legătura Dunării cu Lacul Cuhurlui, brațul Lapteș, derivat din brațul Chilia spre delta secundară etc.
} 
acest motiv extinzîndu-se și spre principalele trecători carpatice (Oituz, Uz, de exemplu). Hidronimele de origine maghiară sînt prezente aproape exclusiv în zona montană şi submontană, constituind o extensie a sistemului toponimic din Secuime, prezența lor fiind la fel de strîns legată de trecătorile carpatice. Hidronimele de origine slavă sînt mai frecvente în zonele de podiș, în special în aria mai înaltă a acestora (Podișul Hotinului, Podişul Sucevei, Podișul Central Moldovenesc). Zonele joase, de cîmpie, prezintă, aparent paradoxal, o pondere mai mare a hidronimelor românești (inclusiv formate pe baza unor împrumuturi lingvistice), fapt care poate fi pus și pe seama (re)populării mai tardive. Din perspectiva dimensiunii cursurilor de apă se remarcă o relație invers proporțională între lungimea acestora și ponderea hidronimelor de origine românească. Se observă o ruptură netă între cursurile de apă sub $25 \mathrm{~km}$ și cele peste această lungime (79,3\% hidronime românești, din care 32,8\% derivate din cuvinte de origine latină, față de numai 47,9\% în cazul cursurilor de apă între 25-100 km și 10,2\% în cazul celor de peste $100 \mathrm{~km}$ ). Ponderea cea mai mare a hidronimelor de origine slavă se înregistrează la cursurile de apă mijlocii, între $25-50$ km iar a celor de origine turcică la cele de peste $50 \mathrm{~km}$.

\subsection{Distribuția și tipologia hidronimelor după semnificație}

Pentru prelucrarea primară a informației referitoare la semnificația hidronimelor au fost reținute 9 categorii: a) hidronime care exprimă morfologia cursurilor de apă, a văilor sau reflectă caracteristicile reliefului local (MORF); b) hidronime inspirate de caracteristicile substratului geologic local (LIT); c) hidronime descriptive, sugerînd însuşiri ale apei/văii (DESC); d) hidronime care invocă elemente faunistice (ZOO) sau floristice (FIT); e) hidronime care sînt legate de anumite activități economice (ECON); f) hidronime care poartă nume de persoane (ANT); g) hidronime care provin de la numele unor localități sau derivă din acestea $\left.(\mathrm{OICO})^{13} ; \mathrm{h}\right)$ hidronime formate prin diminutivare sau derivare.

a. Prima categorie (MORF) deține o pondere importantă (15\%), cele mai frecvente semnificaţii reflectînd:

1) poziția izolată, la obîrșii, 44 de cazuri, printre cele mai reprezentative fiind derivate din temele fund- (Fundoaia, Fundătura, Fundul, 12 cazuri), gîrb- (Gîrbova, Gîrbele, Gîrbosu) etc.;

2) dimensiunea văii, cel mai frecvent fiind invocată lărgimea (Larga, Largul, Valea Mare, 43 de cazuri) sau lungimea (Lungul, Valea Lungă, 18 cazuri);

3) fragmentarea reliefului, mai ales în zona colinară ( 40 de cazuri, cu o frecvența mare a denumirii Valea Rea - 15 situații, Găunoasa, Găureana, Ponoru, Ruptura, Hîrtopu);

4) adîncimea fragmentării reliefului, 20 de cazuri, cel mai frecvent utilizat fiind termenul adînc(frecvent în forma Valea Adîncă) dar și cea est-slavă, hlybok-, cu evoluții fonetice diferite (Hlibocioc, Hlibicioc, Hulbucioc etc.);

5) sinuozitatea cursului sau a văii, 20 de cazuri, ilustrative fiind cele derivate din tema slavă kriv(Crivăț, Crivec) dar și Colacul, Strîmba, Codreava, Pîrîul Întors, Belciugul sau derivate din turcicul çukur, etc.;

6) planeitatea reliefului, 24 de cazuri, utilizînd frecvent termenii șes, podiş dar și neted (Valea Netedă, afluent al Cerlinei în bazinul mijlociu al Prutului, etc.);

7) accesibilitatea văii, exprimată de hidronime precum Putna, Putila, Brodina, Telejna, derivate din cuvinte de origine slavă (put', brod, telèga), 15 cazuri în total;

8) inundabilitatea albiei majore, exprimată cel mai frecvent de tema bahnă (8 cazuri, inclusiv derivate), şar (Șărișor, Șaroș), lapoș, volo(a)că, etc. Sînt specifice vestului Moldovei;

b. Caracteristicile substratului litologic (LIT) sînt mai slab reprezentate, în concordanță cu relieful dezvoltat în cea mai mare parte pe roci moi, friabile care nu ies în evidență prin forme spectaculoase, cu excepția zonei montane și a văii Nistrului mijlociu. Reprezentînd doar 3,2\% din total, aceste hidronime au o frecvență mai mare în zonele amintite unde aflorează la suprafață orogenul carpatic

\footnotetext{
${ }^{13}$ În această situație s-a ținut cont de vechimea oiconimelor, existînd și posibilitatea ca satele să preia numele văilor pe care $s$-au instalat.
} 
sau rocile vechi din soclul Platformei Est-Europene. Cele mai frecvente au la bază apelativul piatră, termen cu o semnificație imprecisă, care trimite însă la duritatea rocii. Dintre cele 41 de hidronime cu această bază, majoritatea sînt de forma Pietrosu (Chetrosu), dar nu sînt rare nici Cremenea, Stînca ori hidronimele dezvoltate din rădăcinile kamen (slavă), taş (turcă) sau köves (maghiară) ${ }^{14}$. Semnificativă este și frecvența hidronimelor care trimit la caracterul friabil al rocilor de substrat, 19 la număr (mai ales dezvoltate din tema glod, dar și humă, nisip ori din teme de origine slavă - $g(h) l i n$ sau nesigură $\operatorname{mol}(n)$.

c. Hidronimele descriptive (DESC) au o frecvență mare (16,5\%), denumirea apelor curgătoare după caracteristicile fizico-chimice fiind frecvent invocată peste tot în lume:

1) descriptorii cromatici au o frecvență foarte mare, în special negru (27 de cazuri), alb (25 de cazuri) şi roşu (22 de cazuri, inclusiv ruginos), reflectînd în general prezența materialelor în suspensie ori culoarea prundișului. Larg răspîndite, aceste hidronime s-au format mai ales plecînd de la cuvinte românești, asociind termeni precum izvor, pîrîu sau vale. Se remarcă totuși, mai ales pentru semnificaţiile alb și negru, o prezență semnificativă a rădăcinilor slave bel și črnı̌ (Bila, Bilca, Bilahoi sau Ciorna, Cernița etc.), mai frecvent în jumătate nordică a regiunii. Culoarea galben a fost atribuită exclusiv unor cursuri de apă din regiunile colinare joase, în sud-estul regiunii ( 5 cazuri, inclusiv prin utilizarea temei turcice sart).

2) descriptorii gustativi, reflectînd compoziția chimică a apei sînt la fel de frecvenți. Cele mai multe hidronime invocă salinitatea apei (41 de cazuri), cu o frecvență mai mare în regiunea subcarpatică dar și în ariile de cîmpie colinară. Două treimi dintre acestea au la bază adjectivul românesc sărat, cu diverse asocieri, dar frecvente sînt și rădăcinile slave sol'- (Soloneț, Solca etc.), în special în Bucovina și nordul Basarabiei, sau slatina, slanŭ, exclusiv în regiunea subcarpatică ${ }^{15}$. În sud-est apar și teme turcice (Alcalia, de exemplu). Mult mai rare sînt epitetele care trimit la alte proprietăţi chimice (dulce, amar, acru).

3) descriptorii care ilustrează scurgerea solidă (tulbure/limpede) nu sînt des întîlniți, avînd o distribuție diferită: în zona de podiș pentru caracteristici de turbiditate și în zona submontană pentru claritatea apei.

4) descriptorii termici au o frecvență relativ redusă, semnificative fiind hidronimele dezvoltate de la adjectivul rece, cu diverse variante (17, unul singur de origine slavă, Studinețul, în bazinul Bîrladului). Absența apelor termale de pe teritoriul Moldovei poate explica raritatea hidronimelor care trimit la temperatura mai ridicată a apei, frecvente în alte regiuni ale țării, îndeosebi pe baza rădăcinii slave topl $l^{16}$.

5) descriptorii care invocă viteza de scurgere a apei, în acord cu predominanța reliefului colinar în care aceasta este, de obicei, medie sînt rar întîlniți. Cei care descriu o viteză de scurgere mare sînt prezenți aproape exclusiv în zona montană (formați atît de la adjectivul repede cît și de la rădăcinile slave bistr-, bîrz-), iar cei care descriu un curs lent, leneș fiind prezenți în zonele de cîmpie. Mult mai frecvente sînt însă hidronimele care indică o scurgere intermitentă a apei, inclusiv în zona montană, expresie a continentalismului climatic specific regiunii. Au fost identificate astfel 47 hidronime care integrează în diverse forme adjectivul sec (Secu, Seaca/Saca, Valea Seacă etc.). În nord-vestul regiunii sînt cîteva hidronime formate de la rădăcina est-slavă sub-(Suha, Suhîi Potoc) iar în sud-vest putem menționa Sușița, format de la o rădăcină sud-slavă. În Bugeac, cu același sens apar hidronime formate din turcicul kuru (Curudere, Curugica).

\footnotetext{
${ }^{14}$ De exemplu: Camenca, afluent al Răutului sau al Prutului, Camînca, afluent al Trotuşului; Taşlîc, afluent al rîului Aliaga, tributar lacului Chitai, Tașbunar, afluent al lacului Cătlăbuga; Cuiejd, afluent al Bistriței.

${ }^{15}$ Interferența între temele slave sol' (specific slavei estice) și slanŭ (specific slavei sudice) pare a se produce în bazinul Trotuşului, unde întîlnim atît Slănicul cît și Solonțul (afluent al Tazlăului). Acesta din urmă este explicat prin filieră maghiară dar are corespondențe și în nord-estul Ucrainei (bazinul Desnei, bazinul Donului).

${ }^{16}$ Singurele excepții sînt: Toplița, numită și Horodnic, în bazinul Sucevei și Toplișoara, în bazinul Negrei Broștenilor, în vecinătatea afluentului Toplița al Mureșului Superior din zona vulcanică neogenă.
} 
6) descriptorii de factură olfactivă constituie o altă categorie, cele mai frecvente hidronime fiind dezvoltate de la adjectivele putred, puturos, impuţit sau indicînd culoarea verde, inclusiv prin rădăcini de origine slavă (Hnila, Zelena, Dofteana, Dîhtineț) sau turcică (Marazli). În unele cazuri, trimit la aspectul murdar al apei (Cacaina, Cacăț), generat de scurgerea solidă. În general, aceste hidronime sînt rare în zona montană și au o frecvență superioară în regiunile de cîmpie colinară.

7) o frecvență semnificativă o au și hidronimele care exprimă impresii pozitive, legate nu atît de cursul de apă cît de aspectul văii (frumos - 14 cazuri, cu mici excepții fiind de origine românească: bun, drag, iubit, bogat etc.), dispersate în întreaga regiune. În acest caz se pot manifesta confuzii, multe din aceste denumiri putînd fi la origine antroponime.

8) mai greu de definit sînt hidronimele care trimit la impresii auditive, legate adesea de viteza de scurgere, de multe ori formate prin onomatopee (Durduc, Duruitoarea) sau folosind termeni sugestivi (Audia, Hangu, Turlui ${ }^{17}$ ).

d. O largă dispersie o au și hidronimele care au fost denumite după elementele fito-faunistice specifice zonei străbătute (ZOO și FIT). În acest caz, parțial și în cele menționate anterior, este dificil de stabilit cu exactitate modul în care a fost atribuită denumirea, putînd fi vorba de fapt de antroponime care au la bază nume de animale sau de plante. Ponderea lor este de 19,7\% împreună (din care 8,8\% sînt zoonime). În ce privește distribuția, se poate observa o frecvență mai mare a fitonimelor în zonele de cîmpie şi în văile marilor rîuri, zoonimele fiind mai des întîlnite în zona montană şi colinară. Cele mai numeroase fitonime sînt cele care au la bază denumirea unor arbuști ( 58 de cazuri), arbori ( 50 de cazuri), plante ierboase (39 de cazuri) sau vegetația de luncă (33 de cazuri). Mai rar, unele fitonime sînt expresia unor asociaţii higrofile (rogoz, stuf, trestie, specifice vegetaţiei de mlaștină) sau a unor activități agricole (plante de cultură ori arbori fructiferi) ${ }^{18}$.

Dintre formaţiunile arbustive, semnificative pentru formarea unor hidronime sînt plante ca socul, cornul, sîngerul și alunul. Frecvente sînt și hidronimele derivate din substantive colective precum tufari, spini sau avînd ca temă rădăcina slavă trŭnŭ (Tîrnauca, Tîrnova).

În ce privește formațiunile forestiere, acestea se conformează, în general, etajelor de vegetație. Astfel, în zona montană sînt mai frecvente hidronimele care invocă prezența bradului, mesteacănului sau a fagului, în zona de deal, a stejarului, teiului sau carpenului, în timp ce ulmul, paltinul și frasinul au o distribuție mai dispersă. Există și excepții, precum Valea Bradului în Podișul Nistrului (raionul Ocnița, Republica Moldova). Fitonimele de origine slavă $(d u b$, buk, berest, lipa $)$ sînt prezente în special în nord-vestul regiunii, dar sînt întîlnite și mai la sud (Lipovăţ, Lipova etc.).

Dintre plantele ierboase, o frecvență semnificativă o au brustur, mai ales în zona montană și bujor, boz sau pelin în zona colinară şi de cîmpie. Pentru vegetaţia de luncă, foarte prolifice sînt hidronimele care indică prezența răchitei, atît cu sufixe românești (Răchitiș, Răchitoasa) cît și slavone, (Răchitna sau, mediat de maghiară, Răcătău). Destul de frecvent apare și salcie sau plop (inclusiv în forme de origine slavă precum Topolița sau Topolovăț). Majoritatea hidronimelor care indică vegetația de luncă sînt localizate în zona colinară, fără a fi absente în restul regiunii.

Zoonimele cele mai frecvente au la bază numele unor mamifere (115 cazuri), cele mai frecvente invocînd prezența lupului, mai ales în forma românească (cu numeroase derivate) dar și slavă (vîlk/vulk/ volk) sau maghiară (farkas), cu o prezență ubicuă și o frecvență paradoxal de mare în regiunile colinare joase sau de cîmpie. La fel de frecvente sînt și hidronimele care invocă prezența unor ierbivore de talie mare (bour, taur, zimbru), predilect în zona montană și de podiș. Destul de des întîlnite sînt și hidronimele care indică prezența porcului (mistreț) sau a ursului, de asemenea în zona de podiș. Cel puțin

\footnotetext{
${ }^{17} \mathrm{Ne}$ referim la posibilitatea derivării denumirii Hangu din maghiarul hang, sunet și la posibilitatea unui calc românesc (sau invers) în cazul Audiei. În ce privește Turluiul care pare la prima vedere turcic, am luat în calcul și posibila derivare din verbul a turlui.

${ }^{18}$ De remarcat prezența unor hidronime care indică prezența unor plante mai rar cultivate în prezent (Pasat/Mălai/Parincea) sau a unor regionalisme (curechi), în special în zona de cîmpie. Dintre arborii fructiferi, cel mai frecvent apare mărul, vișinul și prunul, predilect în zona montană și colinară.
} 
pentru ultimul caz, putem prezuma derivarea de la antroponimul Ursu, fiind greu de acceptat prezența acestui mamifer în zona de silvostepă (Ursoaia, afluent al Botnei, în bazinul inferior al Nistrului, sau Medveja, afluent la Lipcani al Prutului, de exemplu). Posibilităţile de interpretare ale seriei La Ursoi, Ursoiul, Ursoaia sunt mult mai variate, în conformitate cu semnificațiile multiple ale acestora (Ciubotaru, 2007). Căprior (inclusiv sub forma slavă, koza) apare frecvent în hidronime din zona montană, mai rar și în arii joase (Căprioara, afluent al Ceagăi, în bazinul Cogîlnicului). Semnificative sînt și hidronimele care indică prezența unor mamifere dispărute: colunul (Colonița, afluenți ai Cuboltei sau Bîcului, situați în regiuni stepice), plotunul (Platonița ${ }^{19}$, afluent al Șomuzului Mare, Plotunul, afluent al Ozanei) sau cazul deja menționat al bourului și zimbrului, aceștia din urmă în special în aria montană și submontană. Nu lipsesc nici hidronimele care derivă de la nume de animale de talie mai mică precum bursuc/viezure, rîs, vulpe sau chiar şoarece. Unele hidronime au la bază și denumiri ale unor animale domestice, îndeosebi calul (inclusiv în forma slavă kobyla), oaia, vaca, de multe ori legat de activități pastorale, de obicei în zonele joase.

Fauna avicolă a generat mai puține hidronime (42 de cazuri) cu o frecvență remarcabilă a cîtorva specii: corbul (inclusiv sub forma est-slavă, voron), șoimul (inclusiv sub forma turcică, balaban, mai ales în zona de cîmpie), cioara și găina sălbatică (exclusiv în zona montană). Dintre nevertebrate, semnificativă este frecvența hidronimelor formate de la apelativul rac (Racova, Racovăț), în special în zona de podiș.

e. Activitățile economice (ECON) au impus numele a 10\% din hidronimele inventariate. Deși mai puțin frecvente, se remarcă prin prezența ubicuă.

Cele mai numeroase reflectă activități de despădurire și defrișare (33 de cazuri), localizate predilect în zona montană și colinară, cu o frecvență mare a unor termeni care indică modalitatea de eliminare a vegetaţiei naturale (ardere, tăiere, secare, ciuntire etc.). Foarte frecvent sînt integrați în hidronime termeni ca poiană, runc, arșiţă, tăietură, secătură, ciungi, prisacă etc. Strîns legate, se adaugă activităţile de valorificare a resurselor forestiere (tocilă, banc etc.) sau care indică locuirea izolată în arii forestiere (budă), in total alte 24 de cazuri. La fel de frecvente sînt hidronimele impuse de organizarea teritoriului (integrînd termeni precum hotar, branişte, hat, șanţ etc.) sau care indică apartenența la o comunitate rurală (Valea Satului, 8 cazuri, Valea Caselor, 4 cazuri, etc.). O a doua categorie o constituie hidronimele care reflectă practicarea agriculturii, cu integrarea frecventă a unor cuvinte ca siliște sau cîmp (asociate mai ales cu entopicul vale). În zona montană apar și alți termeni, precum holdă sau derivate din slavul sad.

Utilizarea apei este o altă activitate economică frecvent invocată de unele hidronime, fie că este vorba de morărit (7 cazuri), activități piscicole (iaz, iezer), prelucrarea unor materii prime textile (topilă/ tochilă, vîltoare, chiuă) sau pentru consum, mai ales în condiții de semiariditate (cișmea, cainar, nu întîmplător termeni de origine turcică).

f. Derivarea hidronimelor de la antroponime (ANTR), care cel mai adesea desemnează proprietatea, este cea mai frecventă dintre categoriile (19,4\%). Valori mult superioare sînt specifice bazinului Jijiei sau Cîmpiei Bugeacului, arii puternic afectate de colonizarea agricolă (sistematică) în secolul al XIXlea. Marea varietate de forme ține și de numeroasele posibilități de derivare, de la numele propriu-zise (Dumitru, afluent al Tarcăului), la diminutive (Dumitrița, afluent al Siretului Mic) sau la sufixarea care indică cel mai adesea proprietarul (Drăgoiasca, Negoștina, Mihova, Voievodeasa ${ }^{20}$, Brădeasa, Șerboaia, Buhuşoaia etc.). Foarte frecvente sînt hidronimele care poartă nume de persoane care nu mai sînt folosite de multă vreme (Brateș, Trifon, Murgoci, Șandru, Giurgiu etc.) iar în sud-est predomină hidronime al căror nume a fost atribuit după cel al unor căpetenii nogai (Casim, Cantemir, Batîr, Bulat etc.). Foarte frecvente sînt și hidronimele formate prin asocierea termenului valea (Valea lui Constantin, în bazinul lacului Ialpuh, Valea Ungurului, în bazinul lacului Cahul, sau Valea Ilenei în

\footnotetext{
${ }^{19}$ Considerat în MDTM (p. 324) ca fiind derivat de la un nume de persoană.

${ }^{20}$ Considered to be the Romanian translation of the German Fürstenthal (Prisacaru, 2013), although it appears at Gonța with the mention „the creek at Sucevița, XVI-III, 226“ (GONȚA, p. 280).
} 
bazinul Bahluiului). Unele trimit la anumite funcții publice (Vămășoaia, Pîrcălabul etc.).

g. Derivarea hidronimelor din oiconime (OICO) este destul de frecventă $(12,9 \%)$, fie prin utilizarea efectivă a numelui localității (Grigorești, Sălăgeni, în bazinul superior al Siretului, de exemplu), fie prin derivare cu sufixul - easca (Corceasca, Hănțeasca, în acelaşi bazin), cu sufixul -eanca (Gîrceanca, în bazinul Racovei, de exemplu), sau în sintagmă cu entopicul vale (Valea Moișii, afluent al Rîșcăi sau Valea Bălăbănești, afluent al Jeravățului, Valea Trușenilor, în bazinul Bîcului). Sînt și cazuri izolate de asociere cu substantivul matcă (Matca Stănileștilor, afluent al Cerlinei la Mămăliga, raionul Noua Suliță, regiunea Cernăuți) sau prin adăugarea la un hidronim a numelui satului (Suha Stulpicanilor, în bazinul Moldovei, Sovița Șipinților sau Sovița Cozmenilor în bazinul superior al Prutului etc.). Ca regulă generală, hidronimele derivate din oiconime sînt mult mai frecvente în regiunile colinare şi de cîmpie, mai ales în arii care au suportat o masivă colonizare rurală în secolul al XIX-lea (Cîmpia Prutului mijlociu, Cîmpia Bugeacului etc.).

h. Ultima categorie de hidronime după semnificaţie, cele derivate (DER) prin atribuirea unui calificativ cu rol de diferențiere sau prin diminutivare este relativ rară (doar 3\%). Cel mai adesea se utilizează adjectivele mare sau mic şi diminutive cu sufixele -oara, -ica, -ița, -uța, -eț sau -el: Siret - Siretul Mic - Sirețel; Putna - Putna Mică (bazinul Moldovei), Brodina - Brodinioara sau Putna - Putnişoara (bazinul Sucevei), Sărata - Săraţica (bazinul Prutului inferior), Dorna - Dornişoara sau Bistrița Bistricioara în bazinul Bistriței, Milcov - Milcovel sau Lepșa - Lepșuleț în bazinul Putnei vrîncene, Salcia Mare - Salcia Mică și Lunga - Lunguța în bazinul Ialpuhului. În unele cazuri derivatele sînt ierarhizate după dimensiune sau poziție (Ciulucul Mare, Ciulucul de Mijloc și Ciulucul Mic în bazinul Răutului sau Sovățul Mare, Sovățul Mic și Sovățul de Jos, în bazinul Prutului mijlociu). Dintre cele 68 de hidronime din această categorie cele mai multe sînt în zona carpatică și în partea central-sudică a Basarabiei.

Clasificarea tipologică efectuată conform metodologiei deja prezentate a identificat șase arii distincte din perspectiva combinării hidronimelor după semnificație, parțial suprapuse peste cele diferențiate după origine. Contrastul între partea vestică a regiunii în care apar toate cele șase tipuri și cea estică unde se combină doar patru dintre acestea, poate fi privit fie ca un reflex al particularităților cadrului natural, mai complex în vest sau drept consecință a populării mai tardive, corelată cu preponderența hidronimelor derivate din antroponime și oiconome, în est.

Primele două tipuri se disting net prin predominanța hidronimelor care au la bază elemente ale cadrului natural, fiind localizate în cea mai mare parte în vestul regiunii. Diferența dintre ele constă în importanța mult mai mare a hidronimelor care exprimă trăsături morfo-litologice în cazul tipului 1 și o relativă importanță mai mare a hidronimelor descriptive sau derivate din fitonime, în cazul tipului 2. Acesta din urmă poate fi considerat la limită ca reprezentînd un tip carpatic. Alăturarea bazinului Botnei, a părții superioare a văii Nistrului (sectorul moldovenesc) și a părții nordice a bazinului Prutului mijlociu (Vilia - Racovăț - Ciuhur) poate să pară excentrică dar se justifică prin frecvența superioară a morfoși litonimelor (Fig. 2). Tipul 3 reprezintă o variantă a primelor două, diferențiat prin ponderea ușor superioară a hidronimelor formate pe baza antroponimelor și oiconimelor. Localizat exclusiv în partea vestică a regiunii (bazinele Sucevei, Bahluiului și Bîrladului), este cel mai apropiat de profilul mediu al regiunii, avînd ca particularitate ponderea cea mai ridicată a zoonimelor.

Ultimele trei tipuri se disting prin ponderea net superioară a antroponimelor şi oiconimelor, respectiv o mai slabă reprezentare a hidronimelor descriptive. Tipul 4 se diferențiază prin ponderea foarte mare a antroponimelor (peste 30\%) fiind caracteristic Bugeacului și unor părți însemnate din bazinul Prutului mijlociu, zone cu masivă colonizare agricolă în secolul al XIX-lea. Tipul 5 se impune prin ponderea mare a oiconimelor în formarea unor hidronime, situație specifică mai ales unor zone de podiș (bazinul superior al Bîrladului, bazinul inferior al Răutului, bazinul Bîcului, bazinul superior al Prutului etc.). O altă diferență constă în ponderea mare a hidronimelor care exprimă particularități geomorfologice, situație explicabilă în contextul fragmentării reliefului din regiunile menționate. Tipul 6, caracteristic văii Prutului inferior, stepei Bălților, bazinului Bașeului și văii Siretului mijlociu, are ca particularitate o pondere semnificativ 


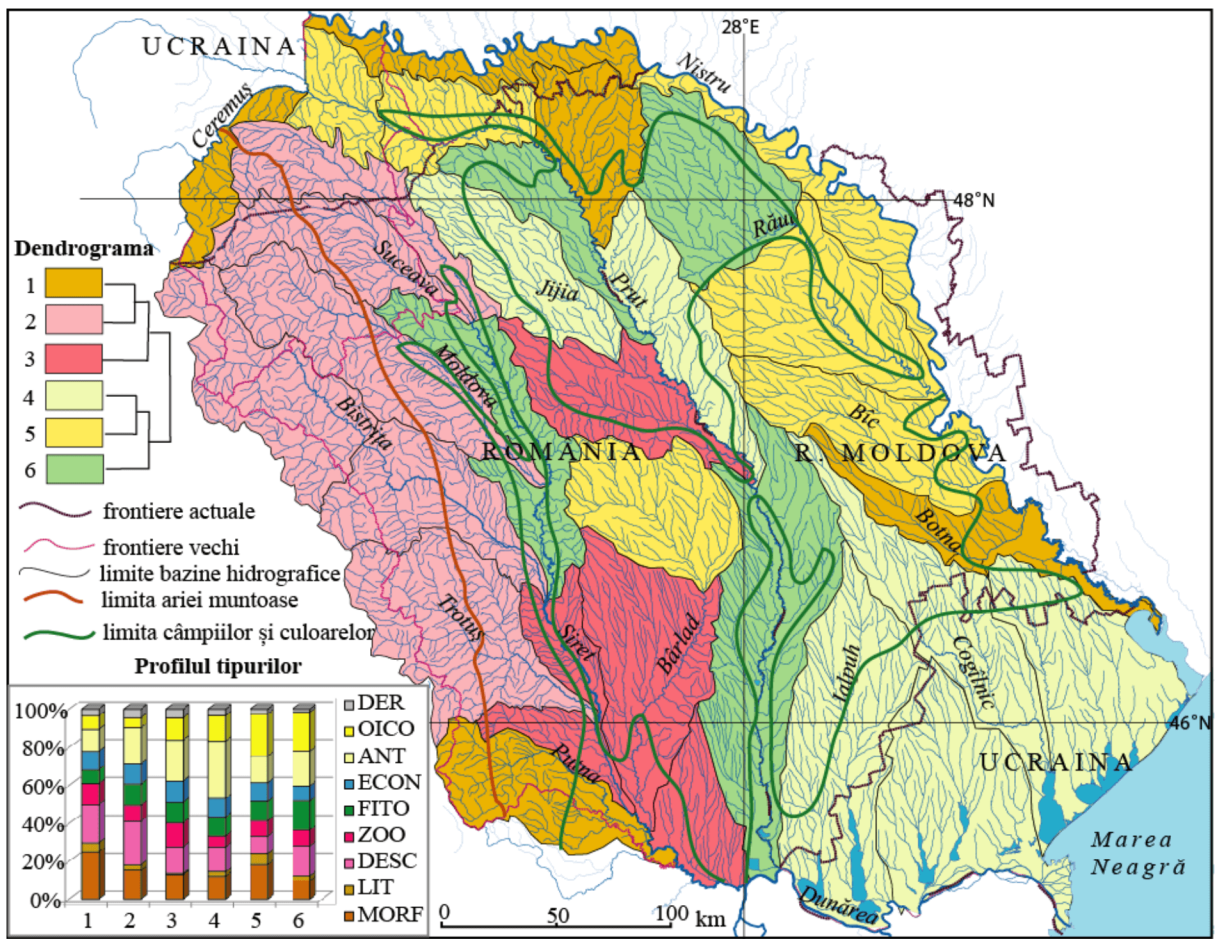

Figura 2: Tipologia hidronimelor din Moldova după semnificație

mai mare a fitonimelor și hidronimelor descriptive, fără ca acestea din urmă să atingă valorile specifice tipurilor 1 sau 2.

Clasificarea scoate în evidență, ca și în cazul originii hidronimelor, o diferență est-vest strîns legată de particularitățile morfologice și biogeografice. Diferențele dintre cele 6 tipuri pot fi interpretate și ca o stratificare cronologică a hidronimelor, mai veche și mai stabilă în partea vestică a regiunii, mai tîrzie şi mai instabilă cu cît avansăm spre estul și sud-estul regiunii. Această ipoteză are la bază prezumția că multe denumiri ale unor văi sau pîraie care derivă din antroponime sau oiconome sînt recente, multe fiind atribuite administrativ.

De altfel, analizată pe mari unități geografice, distribuția categoriilor de hidronime după semnificație scoate în evidență diferențe substanțiale între zona de munte şi zonele joase, de deal și cîmpie. Faţă de ușoara predominanță a hidronimelor care derivă din elemente ale cadrului natural la nivel regional $(54,3 \%)$, în zona montană se înregistrează valori net superioare $(62,9 \%)$. Zona muntoasă se remarcă și prin suprareprezentarea hidronimelor descriptive $(23,4 \%)$ sau a celor derivate din activități economice $(11,2 \%)$. Varietatea peisajului geografic și rolul exploatării resurselor forestiere în evoluția procesului de populare pot explica această situație. În contrast, zonele de deal se disting printr-o suprareprezentare a oiconimelor și a morfonimelor (18, respectiv $16,5 \%$ ), iar cele de cîmpie prin predominanța antroponimelor și a fitonimelor (25,6\%, respectiv 13,1\%). Hidronimele descriptive sînt, în general, mai rare în regiunile joase. Frecvența proceselor geomorfologice și slaba evidențiere a cursurilor de apă (debite reduse, morfometrie simplă) constituie explicații plauzibile pentru particularitățile zonei deluroase iar în cîmpie preferința pentru tipurile de hidronime menționate este corelată cu importanța văilor în organizarea teritoriului și cu evidențierea acestora din punct de vedere floristic în opoziție cu monotonia spațiilor stepice.

\section{Concluzii}

Rezultatele prezentate confirmă importanţa studiului geografic al hidronimelor, în concordanţă cu obiectivul propus: analiza distribuției spațiale a hidronimelor în corelație cu originea și semnificativitatea lor din perspectivă naturală sau uman-geografică. Cele două clasificări întocmite în conformitate cu rigorile 
statisticii descriptive impun existența unor arii distincte, suficient de diferențiate prin frecvența anumitor categorii de hidronime, fie că ne raportăm la origine, fie la semnificația lor.

Se poate afirma preliminar că dispunerea graduală, în trepte, a reliefului dinspre Carpați spre est induce o primă divizare a spaţiului Moldovei istorice: zona montană și submontană iese în evidență prin întrepătrunderea influențelor slave cu cele transilvănene și cu o dominanță a semnificației naturale a denumirilor acordate cursurilor de apă, iar zona stepică a Bugeacului se detașează prin persistența influenței turanice, mai difuză în rest și prin semnificațiile în mare parte de sorginte antropică. Între aceste două spații, distincte geografic, restul teritoriului, suprapus pe cea mai mare parte din Podișul Moldovei se remarcă prin dispunerea graduală nord-sud a influenței slave și printr-un profil mai complex al semnificațiilor, strîns legat de caracteristicile morfo-litologice, biogeografice sau de evoluția sistemului de populare ${ }^{21}$. Personalizarea subunităților fizico-geografice ale Podișului Moldovei din dubla perspectivă abordată este indubitabilă, Cîmpia Jijiei fiind suficient de diferită de Podișul Bîrladului, de exemplu.

O a doua divizare este indusă de factorul politic care, prin dezmembrarea acestui teritoriu cîndva unitar, a impus modificarea substanțială pe alocuri a toponimiei în ansamblu, generînd diferențe care par să separe mai ales Basarabia de vestul Moldovei, dar și Bucovina, în special partea sa nordică. Modificarea denumirii unor hidronime, traducerea sau adaptarea lor în limbile unor populații devenite majoritare este o consecință directă â $^{22}$. Modul în care s-au sedimentat în timp hidronimele au favorizat în cea mai mare parte a Basarabiei derivarea din antroponime și, mai ales oiconime, multe impuse, probabil, odată cu ridicările cartografice moderne cînd au trebuit denumite și văile sau pîraiele de mici dimensiuni, nedocumentate anterior ocupației țariste. Astfel de evoluții pot fi invocate și în restul teritoriului în contexte similare.

\section{Bibliografie}

\section{A. Lucrări de referință}

Brezianu, S. (2002). Identități și solidarități medievale, Corint, București. Butnaru, D. (2011). Toponimia bazinului hidrografic al Neamțului, Alfa, Iași.

Ciubotaru, M. (2001). Oronimia și hidronimia din bazinul superior al Bârladului, Demiurg, Iași.

Ciubotaru, M. (2007). Toponimie şi zoonimie. Observații metodologice şi distincțiii etimologice, în „Anuar de Lingvistică şi Istorie Literară”, tom. XLVII-XLVIII, A, p. 101-111.

Cojocaru, V. (2005). Toponimia văii mijlocii a Trotuşului. Dinamica structurilor toponimice, Demiurg, Iași.

Eremia, A. (2012). Hidronimia bazinului hidrografic al Dunării, în „Buletin de Lingvistică”, 13, p. 66-74.

Eremia, A. (2014). Originea toponimelor, controverse de opinii, etimologii false, în „Philologia”, LVI, p. 62-72.

Eremia, A. (2017). Hidronimia bazinului hidrografic al Nistrului, în „Akademos”, 3, p. 132-138.

Felecan, O. \& Felecan, N. (2015). Straturi toponimice reflectate în hidronimia românească, în „Quaderns de Filologia: Estudis Lingüístics", XX, p. 251-269, Crossref.

Hastie, T. et al. (2009). Hierarchical clustering, în The Elements of Statistical Learning, Springer, New York.

Krahe, H. (1964). Unsere ältesten Flussnamen, Harrasowitz, Wiesbaden.

Lebel, P. (1956). Principes et méthodes d'hydronymie française, Les Belles Lettres, Paris.

Moldovanu, D. (1987). Hidronime românești de origine slavă: Bîrladul, Ialomița, Jijia, în „Anuar de lingvistică și istorie literară”, XXXI, 1986-1987, A, p. 291-312.

\footnotetext{
${ }^{21}$ Prin Podișul Moldovei înțelegem întreaga unitate fizico-geografică dezvoltată pe fundament est-european, cu o fragmentarea deluroasă ori colinară, cuprins între Obcinele Bucovinei și Subcarpați în vest, Cîmpia Română în sud-vest și Nistru. Cuprinde $3 / 4$ din teritoriul Moldovei istorice și este definitoriu pentru aceasta din punct de vedere geografic.

${ }^{22}$ Este o situație mai frecventă în Bucovina unde multe hidronime care apar cu forme românești în dicționarele sau documentele cartografice mai vechi au fost modificate încît abia mai pot fi recunoscute: Porcul, afluent al Putilei, astăzi Porkulin; Izvoraș, afluent al Siretului, astăzi Zvaraș (Zvarici), iar în aval, un alt afluent al aceluiași rîu, Siliștea, fiind astăzi transcris ca Selici; Vîltori, în bazinul Hliniței, afluent pe dreapta al Prutului, astăzi Vivtar; Pisareul, în bazinul Hlibociocului, afluent pe dreapta al Prutului, astăzi, Psiarev, etc. Și în ținutul Hotinului pot fi citate astfel de exemple: Hîrtopul, afluent al Chetroasei, astăzi Krokva sau Surda (aşa cum apare în ARBORE, care spune că numele rusesc este Surta), astăzi Surșa, posibil prin contaminare cu numele unui afluent de pe stînga Nistrului, Surja care confluează în apropiere. Se poate presupune că multe dintre hidronimele minore din nord-vestul Moldovei istorice, astăzi dominant ucrainean din punct de vedere etnic, au dispărut, nefiind consemnate, cele actuale fiind de dată recentă. În acelaşi sens însă, putem presupune că și în restul teritoriului au fost modificate denumiri slave sau turanice originare ale multor hidronime, fiind înlocuite cu denumiri românești.
} 
Moldovanu, D. (2007-2008). Hidronime de origine veche turcică în sudul Moldovei, în „Anuar de lingvistică și istorie literară”, XLVII-XLVIII, p. 9-28.

Peust, C. (2015). How old are the River Names of Europe? A Glottochronological Approach, in „Linguistik Online”, 70 (1), p. 185-218, Crossref.

Prisacaru, A.-M. (2013). Reromânizare toponimică. Cu aplicații la toponimia românească din Bucovina habsburgică (actualele teritorii românești), în Cultură și identitate românească. Tendințe acutale și reflectarea lor în diaspora, Editura Universității „Alexandru Ioan Cuza”, Iaşi.

Raevschi, N. (2006). Hidronime traco-dace având conexiuni etimologice baltice, în „Limba Română”, XVI (7-9), p. 93-111.

Spinei, V. (1999). Marile migrații din estul și sud-estul Europei în secolele IX-XIII, Institutul European, Iași.

Ungureanu, A. \& Boamfă, I. (2006). Toponomastică, Sedcom Libris, Iași.

Urazmetova A.V. \& Șamsutdinova, J. K. (2017). Principles of place names classifications, în „Xlinguæ”, 10 (4), p. 26-33, Crossref. Vennemann, T. (2003). Europa Vasconica - Europa Semitica, Walter de Gruyter, Berlin.

Вербич, С. (2015). Слованско - східнороманска взаємодія гідронімї басейну Анистра: Оригінална назвита структурно адаптовани утворення [Slavic and Eastern Romance interaction in the hydronymy of the Dniester river basin], în „Linguistica”, 55 (1), p. 115-129, Crossref.

Топоров, В.Н. \& Трубачев, О.Н. (1962). Аингвистический анализ гидронимов Верхнево Поднепровья, Академий Наук СССР, Москва.

\section{B. Surse}

ARBORE = Arbore, Z. (2012). Dicționarul geografic al Basarabiei, Sæculum, București.

ATLAS MOLD. = Atlasul Moldovei (1:50 000), Institutul Geografic al Armatei, București, 1892-1898.

FNDG = Fondul național de date geospațiale, [online, consultat în perioada 2016-2018].

GONȚA = Gonța, Al. (1990). Documente privind Istoria României. A. Moldova. Veacurile XIV-XVII (1384-1625). Indicele numelor de locuri, Editura Academiei, București, 1990.

GRIGOROVITZA = Grigorovitza, E. (1908). Dicționarul geografic al Bucovinei, Tipografia I. G. Lahovari, București, 1908.

HARTA BUC. = Iosep, I. (coord.) (2014). Cele dintâi hărţi ale Bucovinei - O retrospectivă necesară, Editura Romstorfer, Suceava. HARTA TOP. = Harta topografică (1:50 000), Direcția topografică militară, [online, consultat în perioada 2015-2018].

HARTA URSS = Harta topografică militară a U.R.S.S. (1:100 000), foile Căușani, Sarata, Cetatea Albă, Tuzla, Tatarbunar, Arciz, Chilia, Izmail, Bolgrad, Galați, Secureni, Chelmenți, Hotin, Novoselița, Cernăuți, Sneatin, Vijnița, Putila și Băile Borșa, [online, consultat în perioada 2008-2012].

HIDR. UCR. = Непокупний, А.П. et al. (1979). Словник гідронімів України, Наукова Аумка, Київ. MDG = Lahovary, Al.G. (1898-1902). Marele Dicționar Geografic al României, I-V, Socec, București. MDтм = Tezaurul toponimic al României. Moldova, II, Mic dicționar toponimic al Moldovei. Structural și etimologic, Partea 1.

Toponime personale (coord. D. Moldovanu), Editura Universității „Alexandru Ioan Cuza”, Iași, 2014.

TTRM = Tezaurul toponimic al României. Moldova (coord. D. Moldovanu). $\mathrm{I}_{1-2}$, Repertoriul istoric al unităţilor administrativteritoriale (1772-1988), Editura Academiei, București, 1991-1992. 